\title{
ПСИХОСОЦІАЛЬНІ ОСОБЛИВОСТІ ЖІНОК, ЯКІ ВЧИНИЛИ НАСИЛЬНИЦЬКІ ЗЛОЧИНИ У СТАНІ АЛКОГОЛЬНОГО СП'ЯНІННЯ
}

\author{
УДК: 616.89-008.441.3-055.2:316.6:343.976
}

\section{Радзевілова Олександра Володимирівна}

Науковий співробітник відділу комплексної судовопсихіатричної експертизи Украӥнського науководослідного інституту сочіальної і судової психіатрії та наркологї МОЗ Украӥни, м. Київ (Украӥна)

\begin{abstract}
Анотація. У статті представлений статистичний аналіз насильницьких злочинів, скоєних жінками. В результаті комплексного дослідження жінок, які проходили судову психіатричну та комплексну судову психолого-психіатричну експертизу (за період 2010-2016 рр.), виокремлені деякі характеристики такої категорї злочинниць: психосочіальні характеристики жінок, притаманний їм типовий стиль реагування у суб'єктивно проблемних ситуаціях, особливості стосунків з потерпілим у провадженні, їх характеристики. Розглянуто індивідуальні характеристики складу правопорушень, які вчиняли жінки у стані алкогольного сп'яніння. На основі порівняльного аналізу наведені відмінності складу насильницьких злочинів, щчо вчиняли жінки у стані сп'яніння та поза таким станом. Розглянуто тезис про вплив алкоголю на злочинну поведінку жінок під час вчинення суспільно-небезпечних діянь, щуо втілюється в обставинах правопорушення.
\end{abstract}

Ключові слова: жіноча злочинність, насильницькі злочини, стан алкогольного сп'яніння, психосочіальні характеристики.

Постановка проблеми. Феномен жіночої злочинності розглядався у кримінологічній науці ще з часів перших спроб типологізації злочинців (Ч. Ламброзо). До найчастіших та сугубо жіночої сфери злочинної діяльності класично відносили проституцію та вбивство власної дитини. Умови та причини формування злочинної поведінки жінок тривалий час пов'язували з позиції соціологічного напрям- ку, тобто роллю жінки у суспільстві (М. Гернет, А. Кетле, А.-М. Геррі). Із зміною такої ролі з'явились ще одні характерні для жінок злочини - у службовій сфері (пов'язані з виконання службових обов'язків).

На сьогоднішній день очевидні різкі

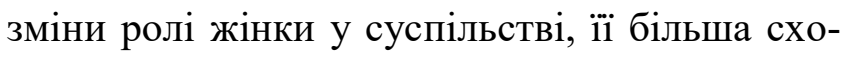
жість до чоловічої; це зумовлює й певне наближення поведінки жінок до чоловічої, в то- 
му числі й у вживанні психоактивних речовин. Внаслідок вищезазначеного розповсюдженість зловживання спиртними напоями зростає не тільки серед чоловічого населення України. Згідно з статистичними даними різних досліджень, Україна входить до п’ятірки найбільш «питущих» націй. 3 аналізу В. Шаповалова та співавторів за даними 22010 року Україна за питомою вагою жіночої алкоголізації серед країн СС відноситься до країн з середнім рівнем вживання алкоголю [1].

За деякими даними під час вчинення агресивних злочинів (вбивство, тяжкі тілесні ушкодження) алкогольне сп'яніння спостерігається у $72 \%$ випадків, а в осіб із синдромом залежності від алкоголю рівень агресивної поведінки є дуже високим та становить від 50 до 60\% (А. П. Петрюк, 2004; 3. Н. Алієв, Н. А. Алієв, 2004).

Сімейно-побутові аспекти життя жінок, домашнє насильство, і як наслідок наявність актуальної психотравмуючій ситуації, іноді й тривалу, - це ті фактори, які можуть слугувати підгрунтям злочинної поведінки жінки, особливо у разі формування виразних емоційних станів на момент суспільно-небезпечного діяння. Проте, зміни соціальних ролей, розповсюдженість вживання психоактивних речовин, відкривають інший аспекти жіночої злочинності - злочини у стані алкогольного сп'яніння.

За дослідженням Н. А. Сирота та Н. I. Зенцова (2010) особи, які мають залеж- ність від алкоголю виявляють тенденцію переоцінювати інтенсивність емоцій, навіть щодо нейтральних обличь, виявляли порушення у розпізнаванні емоційних виразів; вони виявляли знижені можливість до міжособистісного пізнання та адекватність розпізнавання поведінки інших, що у сукупності відображають слабкість регуляційної функції в міжособистісному спілкуванні. За результатами їхнього дослідження виявилось зниження здатності осіб, що вживають алкоголь, осягати результати поведінки, передбачати їх наслідки та недостатність розуміння зв'язку між поведінкою та її наслідками [2].

А. В. Савченко відмічає, злочини, що вчиняються в стані алкогольного чи наркотичного сп'яніння, відносить до імпульсивних злочинів, які супроводжуються бездумністю, безцільністю, невідповідність зовнішнім обставинам [1, с. 62-63]. Такий самий імпульсивний характер формування злочинної діяльності під впливом алкоголю наводиться у результаті аналізу деяких судово-слідчих прикладів, 3 яких вбачається, що проаналізовані злочини були вчинені під час сварок, що виникали раптово на фоні алкогольного сп'яніння [1].

3 судово-психіатричної експертної практики відомо, що навіть у виражених ступенях алкогольного сп'яніння в особи зберігається певний контакт із оточуючим середовищем, здійснюється контроль над своєю поведінкою. Зміни зумовлені станом сп'яніння відображаються, в тому числі й в емоційній не- 
стійкості, подразливості, швидкому переключень уявлень у рухові акти, спробах передчасної реалізації виниклих намірів і загальному психомоторному збудженні. В свідомості хворого можуть легко з'являтися неочікувані, дивні думки, що негайно реалізуються в дії. [4]

Аналіз останніх досліджень і публікацій. Питанню жіночої злочинності присвячені дослідження Ю. Антоняна, А. Бадири, Я. Гілянського, В. Меркулової, В. Серебрякової, Т. Продан, М. Чаплик. Деякі питання жіночої злочинності у світлі судово-психологічної оцінці детально досліджувався Ф. С. Сафуновим.

Існують дослідження 3 позиції судовопсихіатричного експертного підходу до феномену жіночої злочинності та вживання психоактивних речовин (А. М. Мельник, 2010; Н. Ю. Васильєва, 2016; О. П. Олійник, 2017).

Інші дослідження відмічають роль алкоголю не тільки у ситуаційній злочинній поведінці особи. В. Батиргареєва (2013) відмічає значну роль алкоголізації у формування рецидивної злочинності жінок [5].

Проте, існуючи дослідження проведені на обмеженому матеріалі та не торкаються проблеми вчинення насильницьких дій у стані алкогольного сп'яніння.

Мета: проаналізувати психосоціальні властивості жінок, які вчинили суспільнонебезпечні діяння (СНД) проти життя та здоров'я особи у стані алкогольного сп'яніння та структуру таких правопорушень.

\section{Виклад основного основного матеріа-} лу і результатів дослідження. Аналіз базується на основі дослідження 169 випадків судово-психіатричних та комплексних судових психолого-психіатричних експертиз щодо жінок, які притягувалась до кримінальної відповідальності за статтями Кримінального Кодексу України, які містять безпосереднім або додатковим об'єктом злочинного посягання життя та здоров'я особи (за період 2010-2016 роки). Усю вибірку було розподілено на 2 групи осіб в залежності від об'єкту злочинного посягання. До першої групи увійшли жінки, які притягувалась до кримінальної відповідальності за злочини проти життя та здоров'я особи (ст. ст. 115, 117, 118, 121, 122, 127). До другої групи увійшли випадки притягнення до відповідальності жінок за злочини, які мали додатковим об'єктом - життя та здоров'я особи (ст. ст. 152, 156, 187, 296).

Під час психологічного обстеження використовувались стандартні методики дослідження когнітивної та особистісної сфер підекспертних (методика дослідження психологічного анамнезу, комплексна методика дослідження психологічних особливостей пам'яті (тест зорової та слухової пам'яті, корткочасної, оперативної пам'яті, пам'яті на числа, образи, тощо), комплексна методика дослідження рівня та перебігу процесів мислення (класифікація, виключення, виділення суттєвих ознак, утворення простих та складних аналогій, пояснення метафор, прислів’ї, визна- 
чення закономірностей, тощо), методика Леонгарда-Шмішека та спеціальні методики у сфері судово-експертної діяльності: методика судово-психологічного дослідження у кримінальних справах та методика експертної оцінки афективних реакцій та особливих емоційних станів. Усі вищезазначені методики зареєстровані у Реєстрі методик проведення судових експертиз. Експертне дослідження грунтувалось на всебічному дослідженні матеріалів кримінального провадження, результатах психіатричного огляду та психологічного обстеження, із подальшим співставленням та аналізом отриманих даних.

3169 випадків експертного дослідження насильницьких злочинів у 133 випадках безпосереднім об'єктом злочинного посягання були життя та здоров'я особи. 3 них в 16 випадках експертними комісіями лікарів психіатрів виносились рішення щодо неможливості підекспертної усвідомлювати значення своїх дій та (або) керувати ними на період правопорушення. В 3 випадках експертною комісією виносилось рішення щодо неповної здатності підекспертних усвідомлювати значення своїх дій та (або) керувати ними на період правопорушення у зв'язку із встановлений лікарями судово-психіатричними експертами їм психічним розладом. Дані випадки виключались для подальшого статистичного аналізу та у даній статті.

В 111 випадках експертною комісією виносилось рішення щодо повної здатності осіб усвідомлювати значення своїх дій та (або) керувати ними на період вчинення злочину. В 3 випадках судовими психологами експертами встановлювався суттєвий вплив специфічного емоційного стану на поведінку підекспертної та іiі регуляцію на період правопорушення.

3114 випадків проведення експертного аналізу стосовно жінок, які притягувались до кримінальної відповідальності за агресивні злочинні дії проти життя та здоров'я 79 осіб (69,3 \%)вживали алкогольні напої на період вчинення злочину (група А), 35 осіб (30,7 \%) на період злочину не перебували у стані алкогольного сп’яніння (група Б).

В групі А відомості щодо наявності стану алкогольного сп'яніння підекспертної на період СНД були відомі з: 32 випадки (40,5 \%) - показання свідків, 7 випадків $(8,9$ \%) - медичної документації; показань самої підекспертної - 40 випадків (50,6 \%).

Аналіз соціальних характеристик підекспертних дозволив виокремити наступні особливості. Переважна більшість підекспертних обох груп мали середню спеціальну освіту ( $\mathrm{A}=36,7 \%, \mathrm{~B}=57,1 \%$ ). Серед підекспертних групи А переважали жінки, які не мали постійного місця роботи на період СНД (58,2 \%). В іншій групі розподіл підекспертних між тими хто не працював на період СНД або мав постійне місце роботи не відрізнявся (40\%). В групі А переважали жінки, які проживали із співмешканцем (34,1%) або були офіційно 
одружені (29,1 \%), вагома частка жінок були розлучені (25,3\%). Жінки групи Б були заміжні в 31,4\%, проживали разом 3 співмешканцем $-25,7 \%$, розлучені $-17,1 \%$.

Асоціальні/девіантні форми поведінки в анамнезі, з аналізу матеріалів кримінальних правопорушень, мали: 59,5\% (А) та 31,4\% (Б). При цьому, неблагополучні умови виховання (позбавлені батьківського піклування, алкоголізація батьків, тощо) за відомостями самих же підекспертних мали: 26,6\% (А), 20\% (Б).

Притягнення до кримінальної відповідальності у попередні роки мали $17,7 \%$ (А) та 17,1\% осіб (Б).

В подальшому, за результатами експертної комісії відмічались достатньо велика частина підекспертних з ознаками педагогічної занедбаності (A=50,6\%, Б=51,4\%).

В мотиваційній сфері підекспертних більшою частиною переважали практично орієнтовані інтереси, їх побутовий характер. Проте, лише в групі Б в 31,4\% випадків були встановлені соціально-позитивні, сімейні настанови, а в групі А такі випадки були поодинокими.

В цілому, такі характеристики особистості як невисокий рівень загальної обізнаності, низька сформованість пізнавальної активності відображаються у повсякденній діяльності жінок та втілюються у невисокому рівні домагань, спрощеності та практичності інтересів, їх обмеженості.

3 аналізу особливостей правопорушен- ня, його складових, відомо, що у 99 випадках $(86,8$ \%) потерпілими були особи чоловічої статі ( $\mathrm{A}=88,6 \%$ та $\mathrm{B}=82,8 \%)$. Потерпілими в групі А у 55,7 \% випадках були родичі підекспертних (з них 72,7 \% - чоловіки підекспертних), 34,1 \% випадках — особи з найближчого соціального оточення. При цьому, в даній групі були випадки, коли потерпілі у провадженні не мали стосунків з підекспертними: раніше незнайомі особи - 5,0 \%; формально знайомі особи - 5,0 \%. Частіше це були наглядно знайомі особи або коло компанії, з якими підекспертні разом вживали алкогольні напої. В групі Б відсутність зв'язку (стосунків) з потерпілим була в поодиноких випадках. В цій групі 57,1 \% — це були родичами підекспертних (з яких в 55,0 \% — це їх чоловіки); в 34,2\% випадків - потерпілими були особи з найближчого соціального оточення.

За результатами аналізу, характеризуюча інформація особи потерпілого містилась у матеріалах провадження, зокрема, у показах свідків, лише у 40 випадках $(\mathrm{A}=50,6 \%)$ та 20 випадках $(Б=57,1 \%)$.

Так, у групі А щодо потерпілих у більшості випадках в матеріалах провадження містились негативні характеристики (описувались такими, що ведуть асоціальний спосіб життя, періодично вживали психоактивні речовини, в стані алкогольного сп'яніння вчиняли бійки, сварки) - 36,7\%, лише в 13,9\% потерпілі характеризувались позитивно або мали формально-позитивні характерис- 
тики з місця проживання / роботи.

При цьому, самі підекспертні в 29,1% описували свої відносини з потерпілим як гарні, дружелюбні.

Стосовно іншої групи аналіз показав, що у провадженнях за злочини, які вчиняли жінки поза станом алкогольного сп'яніння, в 31,4 \% потерпілі негативно характеризувались свідками; такі характеристики більшою мірою торкались агресивної поведінки потерпілих по відношенню до самих підекспертних (в 63,6\% свідки описували часті конфліктні ситуації на фоні алкогольного сп'яніння потерпілого, а в 36,4 \% такі конфлікти відбувались поза станом сп'яніння потерпілого).

Лише в 11,4 \% відносини між потерпілим та підекспертною були зображені підекспертними як гарні, дружні.

Загалом, незважаючи на наявні в матеріалах провадження чисельні об'єктивно підтверджені негативно характеризуючі дані стосовно відносин з потерпілим, лише невелика кількість підекспертних групи Б суб'єктивно сприймали такі відносити як складні, емоційні, психотравмуючи, такі, що сприяють накопиченню негативних емоційних переживань $(A=21,5 \%, 5=40,0 \%)$.

В матеріалах кримінального провадження в 33 випадках $(28,9$ \%) були відсутні характеризуючи дані стосовно особи підекспертної: 26,6 \% (А), 34,2 \% (Б). Негативно характеризувались (свідками, оформлені характеристики 3 місця роботи/з місця проживання) в більшій мірі жінки групи А. Так, 37,9 \% характеризувались такими, що ведуть аморальний та/або асоціальний спосіб життя, в стані алкогольного сп'яніння були схильні до вияву різних форм агресії. В цій групі лише в 7,7 \% підекспертні позитивно характеризувались, та в 27,8 \% у матеріалах справи містились формально-позитивні характеристики 3 місця роботи/проживання.

Для жінок іншої групи (Б) навпаки більш характерними були позитивні характеристики за матеріалами провадження (37,1\%), негативно характеризувались $28,6 \%$ осіб (3 них 6 осіб як такі, що вели асоціальний/ аморальний спосіб життя, 4 особи описувались свідками як конфліктні, схильні до вияву фізичної агресії).

При цьому, в результаті комплексного аналізу результатів проведених психодіагностичних методик, узагальнюючого аналізу висновків експертного дослідження, у жінок обох груп переважав однакових стиль реагування на суб'єктивно проблемні ситуації. Так, збудливі форми реагування були характерні для 56 підекспертних група А (70,8 \%) та 18 підекспертних групи Б (51,4%).

Аналізу матеріалів провадження показав, що в групі А в 68 випадках (86,1 \%) потерпіли на період СНД перебували у стані алкогольного сп'яніння та в 61 випадках $(77,2 \%)$ нанесення тілесних ушкоджень відбувалось під час конфлікту на фоні сумісного вживання алкогольних напоїв; в таких випадках найчас- 
тіше знаряддям злочину виступав ніж, приготовлений для нарізання «закуски». Лише в 18 випадках (22,8 \%) жінки вживали алкогольні напої перед СНД окремо від потерпілого. Натомість у групі Б стан сп'яніння потерпілого на період СНД відмічався в 17 випадках $(48,6 \%)$.

В подальшому, в посткримінальний період в поведінці осіб, які перебували у стані алкогольного сп'яніння на період СНД, відмічалась байдужість до скоєного. Так, 24,1 \% взагалі не звернули увагу на факт нанесення тілесних ушкоджень потерпілому (11,4 \% випадки в групі Б), продовжували вживати алкогольні напої або лягали спати. В подальшому, під час надання показань жінки групи А в 29,1 \% не могли пояснити причину власних дій або пояснювали їх перебуванням в стані алкогольного сп'яніння, 15,2 \% жінок трактували свої дії як випадкові (наприклад, «потерпілий сам напоровся на ніж»).

Висновки. Агресивні злочині дії проти життя та здоров'я особи в переважній більшості випадків вчинюють жінки у стані алкогольного сп'яніння. Потерпілими у даних категоріях справ є особи з найближчого соціального оточення жінки (родичі, друзі, тощо). Чоловіки найчастіше стають потерпілими у таких категорій справ. При цьому, стан алкогольного сп'яніння на період СНД в таких кримінальних справах досить часто спостерігається й у потерпілих.

Особливою рисою злочинів, які вчиня- ються жінкою у стані сп'яніння є те, що в поодиноких випадках потерпілими стають малознайомі особи (тобто не мають жодних стосунків 3 жінкою) під час сумісного вживання алкогольних напоїв. Цікавим є факт, що на ряду 3 негативними характеристиками жінок й самі потерпілі мають негативні характеристики; найчастіше вони характеризуються як такі, що зловживають алкогольними напоями, конфліктні, які часто вчиняють бійки у стані сп'яніння. Однак, в цих випадках не можна однозначно стверджувати, що жінки наносять тілесні ушкодження у результаті впливу специфічного емоційного стану (наприклад, кумулятивного афекту, фрустрації) не тільки через стан алкогольного сп'яніння на момент СНД, а безпосередньо через відсутність кумуляції таких негативних емоцій. Жінки, незважаючи на об'єктивно конфліктний характер взаємовідносин 3 особою, далеко не завжди суб'єктивно оцінюють ситуацію відповідним чином.

До особливостей злочинів, які вчиняли жінки у стані сп'яніння, $є$ й те, що велика частина жінок у посткримінальний період взагалі не можуть згадати обставини правопорушення, пояснюють власні злочинні дії впливом алкоголю.

Вагомою $є$ частка злочинів, які вчинюються жінками під час сумісного вживання алкоголю та у ході звичних для них конфліктів, сумісних бійках. В таких випадках попередні стосунки між жінкою та потерпілим, конфліктна ситуація мають другорядне зна- 
чення. На перший план виступає саме вплив алкоголю на сприймання актуальної ситуації. Стан алкогольного сп'яніння підвищує емоційність сприйняття та імпульсивність реагування, полегшує реалізацію асоціальних поведінкових реакцій. Саме такі особливості алкогольного сп'яніння часто й реалізуються в імпульсивності вибору знаряддя правопорушення («те що було найближче до рук»). Зважаючи на те, що такі правопорушення супроводжувались сумісним вживанням алкогольних напоїв разом з потерпілим, а конфлікти відбувались під час застілля, то найпоширеніше знаряддя злочину - кухонний ніж. Такі механізм вчинення правопорушення та посткримінальної поведінки у даної категорії осіб відображає в переважній більшості вплив алкоголю, що у поєднанні з психосоціальними характеристиками жінок, полегшує асоціальний тип вирішення конфліктної (зазвичай звичної для такої категорії жінок) ситуації, підсилюючи притаманні для жінки індивідуальні особливості та актуалізує провідні мотиваційні чинники поведінки.

Вивчення структури насильницьких злочинів та психологічних характеристик жінок, що їх вчинили, дозволить відмежувати різні категорії злочинних дій (наприклад, емоційних, корисливих, ситуаційно обумовлених) для подальшої розробки психокорекційних програм для такої категорії злочинців з метою попередження їх повторюваності. Особливе значення має подальше дослідження предик- торів формування насильницьких злочинних дій, що вчиняють жінки, що дозволить виокремити специфічні кластери для створення спеціальних програм попередження правопорушень.

\section{Перелік використаних джерел:}

1. Шаповалов В. В. Судово-фармацевтичне та криміналістичне вивчення фактів убивств, скоєних жінками у стані алкогольного сп'яніння / В. В. Шаповалов, В. В. Шаповалов, В. О. Шаповалова, В. О. Радіонова. // Теорія і практика правознавства. - 2015. - Вип. 1. [Електронний ресурс]. Режим доступу: http:// nbuv.gov.ua/UJRN/tipp_2015_1_31

2. Сирота Н. А. Исследование социального познания и социального интеллекта у лиц, зависимых от психоактивных веществ / Н. А. Сирота, Н. И. Зенцова // Медицинская психология в России. - 2010. - № 4. [Електронний pecypc]. Режим доступу: http:// www.medpsy.ru/mprj/archiv_global/2010_4_5/nomer/ nomer01.php

3. Савченко А. В. Мотив і мотивація злочину / А. В. Савченко. - К.: Атіка, 2002. - $144 \mathrm{c}$.

4. Левенеиь I. В. Судова психіатрія: Навчальний посібник / I. В. Левенець. - Тернопіль: Економічна думка, 2005. - $328 \mathrm{c}$.

5. Батиргареєва В. С. Протидія поширенню алкоголізму - пріоритетний напрям державної політики у сфері боротьби зі злочинністю / В. С. Батиргареєва. // Питання боротьби зі злочинністю : зб. наук. пр. - Харків: Право, 2013. - Вип. 25. - С. 35-44.

\section{References (Transliteration):}

1. Shapovalov $\quad V . \quad V$. Sudovo-farmatsevtichne ta kriminalistichne vivchennya faktiv ubivstv, skoenih zhinkami u stani alkogolnogo sp'yaninnya / V. V. 
Shapovalov, V. V. Shapovalov, V. O. Shapovalova, V. O. Radionova. // Teoriya i praktika pravoznavstva. - 2015. Vip. 1. [Elektronniy resurs]. Rezhim dostupu: http:// nbuv.gov.ua/UJRN/tipp_2015_1_31.

2. Sirota N. A. Issledovanie sotsialnogo poznaniya i sotsialnogo intellekta u lits, zavisimyih ot psihoaktivnyih veschestv / N. A. Sirota, N. I. Zentsova. // Meditsinskaya psihologiya v Rossii. - 2010. - № 4. [Elektronniy resurs]. Rezhim dostupu: http://www.medpsy.ru/mprj/ archiv_global/2010_4_5/nomer/nomer01.php.

3. Savchenko A. V. Motiv i motivatsiya zlochinu / A. V. Savchenko. - K.: Atika, 2002. - 144 s.

4. Levenets $I$. V. Sudova psihiatriya: Navchalniy posibnik / I. V. Levenets. - Ternopil: Ekonomichna dumka, 2005. $328 \mathrm{~s}$.

5. Batirgareeva $V$. S. Protidiya poshirennyu alkogolizmu prioritetniy napryam derzhavnoyi politiki u sferi borotbi zi zlochinnistyu / V. S. BatirgareEva // Pitannya borotbi zi zlochinnistyu : zb. nauk. pr. - Harkiv : Pravo, 2013. - Vip. 25. - S. 35-44.

\section{Radzevilova Oleksandra}

Research scientist of Department of complex forensic psychiatry examination Ukrainian research institute of social and forensic psychiatry and drug abuse, Ministry of health of Ukraine, Kyiv (Ukraine)

\section{PSYCHOSOCIAL CHARACTERISTICS OF WOMEN WHO COMMITTED VIOLENT CRIMES IN THE STATE OF ALCOHOL INTOXICATION}

\section{ABSTRACT}

This article is dedicated to the issue of female criminality; namely, individual characteristics and structure of violent crimes; and study of possible predictive factors of how such behavior is formed. Today we are able to examine other aspects of female behavior: violent criminal actions, which have earlier been more typical in males. Such changes are stipulated by the fact that women have been accepting more "male" roles, including consumption of psychoactive substances.

The conducted research stipulates that a significant share of aggressive crimes among females are committed in the state of alcohol intoxication and are not always directed against their closest social circle. Crimes committed in the state of alcohol intoxication are characterized exclusively by the absence of any relationships with the victim of a crime; namely, socially dangerous actions committed in the course of joint consumption of alcoholic beverages. As a result of summarizing the psychological research data and materials of criminal proceedings (conclusions of forensic examinations), comparative analysis conducted in women in regards to their characteristics allowed to pinpoint their psychosocial characteristics, peculiarities in relationships with others, the most common type of response in conflict situations, and potential influence of mentioned factors on further criminal behavior. It was established that despite the absence of statistical difference in conditions of upbringing of women (deprivation of parental care, alcoholic parents, etc.), asocial forms of behavior in the past were mainly demonstrated by women who later on committed crimes in the state of alcohol intoxication. The research cites that low level of obtained education, as established, later on reflected such characteristics in women as low level of general knowledge, underdeveloped cog- 
nitive activity, which was manifested itself in low -level demands, primitiveness, practicality and narrowness of interests.

In this research, we draw attention to characteristics of the victim for the purpose of a more profound analysis of how criminal behavior is formed in females. This analysis proved that one of the predictive factors of violent actions is influence of alcohol on a person. This, along with psychosocial characteristics of females, alters perception of conflicted relationships with others, hinders prediction of far-going consequences of one's own behavior and stipulates the manner of interaction with the environment. Through studying the crime structure and social interaction of females, we have presented an opinion on a crucial affect of alcohol on the behavior during a violation of law. This is especially obvious in how impulsive the choice of weapon is during the offense as well as in post-criminal behavior of offenders.

Key words: female criminality, women criminality, violent crimes, alcohol intoxication, psychosocial peculiarities, psychosocial characteristics.

\section{Радзевилова Александра Владимирова}

Научный сотрудник отдела комплексной судебнопсихиатрической экспертизы Украинского научноисследовательского института сочиальной и судебной психиатрии и наркологии МЗ Украины,, г. Киев (Украина)

\section{ПСИХОСОЦИАЛЬНЫЕ ОСОБЕННОСТИ ЖЕНЩИН СОВЕРШИВШИХ НАСИЛЬСТВЕННЫЕ ПРЕСТУПЛЕНИЯ В СОСТОЯНИИ АЛКОГОЛЬНОГО ОПЬЯНЕНИЯ}

Аннотация. Статья посвящена вопросу женской преступности, а именно индивидуальных характеристик и структуры насильственных преступлений; изучению возможных предикторов формирования такого поведения. Современность открывает другие аспекты женского поведения - насильственные преступные действия, что ранее было больше характерным для мужчин. Такие изменения оговариваются наличием у женщин более мужских ролей, в том числе и по употреблению психоактивных веществ.

Из проведенного исследования следует, что значительная доля агрессивных преступных действий совершаются женщинами в состоянии алкогольного опьянения и не всегда против ближайшего социального окружения. Исключительно для преступлений, совершенных в состоянии опьянения, характерно отсутствие каких-либо отношений с потерпевшим; общественно-опасное действие совершаются во время совместного употребления алкогольных напитков. Проведенный сравнительный анализ характеристик женщин, в ре- 
зультате обобщающих данных психологического исследования и материалов уголовных производств (заключений судебнопсихиатрической экспертизы), позволил выделить их психосоциальные характеристики, особенности отношений с окружающими, типичный тип реагирования в конфликтных ситуациях и их возможное влияние на дальнейшее криминальное поведение. Установлено, что, несмотря на отсутствие статистической разницы в условиях воспитания женщин (так называемы неблагоприятные условия воспитания), асоциальные формы поведения в анамнезе в большей степени проявляли женщины, которые в дальнейшем совершали преступления в состоянии опьянения. В статье в результате анализа установлено, что невысокий уровень полученного образования отражался в дальнейшем в таких характеристиках женщин как невысокий уровень общей осведомленности, низкая сформированность познавательной активности. Это в свою очередь воплощалось в низком уровне притязаний, упрощенности и практичности интересов, их ограниченности.

В приведенном исследовании уделено внимание характеристикам потерпевшего для более глубокого анализа формирования преступного поведения женщины. На основе анализа установлено, что одним из предикторов насильственных действий является влияние алкоголя на женщину, что наряду с психосоциальными характеристиками женщин меняет восприятие конфликтных отношений с другими, снижает прогноз дальнейших результатом собственного поведения и обусловливает стиль взаимодействия с окружающими. В результате изучения структуры преступлений и социального взаимодействия женщин приведен тезис об определяющем влиянии алкоголя на поведение во время правонарушения, что особенно просматривается в импульсивности выбора орудия правонарушения и их посткриминальном поведении.

Ключевые слова: женская преступность, насильственные преступления, состояние алкогольного опьянения, психосоциальные характеристики.
Дата отримання статті: 10.10.2017 Дата рекомендації до друку: 15.10.2017 